Obere Extremität 2014 · 9:276-279

DOI 10.1007/s11678-014-0276-y

Received: 30 April 2014

Accepted: 26 June 2014

Published online: 11 September 2014

c) Springer-Verlag Berlin Heidelberg 2014

Peter J. Millett ${ }^{1,2}$ - Daniel Rios ${ }^{3}$. Frank Martetschläger ${ }^{4}$ Marilee P. Horan ${ }^{1}$

${ }^{1}$ Center for Outcomes-based Orthopaedic Research, Steadman Philippon Research Institute, Vail, USA

2 The Steadman Clinic, 181 West Meadow Drive, Suite 400, Vail, USA

${ }^{3}$ Instituto Tecnologico y de Estudios Superiores de Monterrey, Monterrey, Mexico

${ }^{4}$ Clinic for Trauma Surgery, Emergency Department, University Hospital

Rechts der Isar, Munich Technical University, Munich, Germany

\title{
Complications following subpectoral biceps tenodesis with interference screw fixation
}

The long head of the biceps tendon is frequently a cause of anterior pain in the shoulder. It has been reported that subpectoral biceps tenodesis reliably improves function and relieves pain [1]. Various open and arthroscopic techniques for biceps tenodesis with different fixation methods have been described. Some of the indications for performing biceps tenodesis are: intractable biceps tendinosis with or without labral pathology, biceps tears involving $50 \%$ or more of the tendon, medial subluxation of the biceps tendon and combined subscapularis tears and biceps subluxation, where tenodesis is performed to protect the subscapularis repair $[2,3]$.

It has been reported that subpectoral biceps tenodesis with an interference screw is a viable treatment for patients with the indications given above [3], but as in any other surgical procedure, complications exist. Complications following supbectoral biceps tenodesis have been described by several authors including failure of hardware, hematoma, seroma, infections, bioabsorbable screw reaction, persistent bicipital pain, neurovascular injury, damage to the brachial artery, screw prominence and fractures $[4,5]$.

The purpose of this study was to report the complication rate after subpectoral biceps tenodesis using interference screw fixation. The hypothesis is that subpectoral biceps tenodesis is a safe and effective method for treating long head of the biceps pathology with a low complication rate.

\section{Methods}

This study had prior Institutional Review Board approval. A data registry was searched for all patients who had a biceps tenodesis over a period of 5 years (November 2005-June 2011) and 636 patients were located who underwent biceps tenodesis by the same surgeon. Patients who underwent subpectoral tenodesis with intereference screws using a standardized technique were included in the analysis. Soft tissue tenodesis, arthroscopic tenodesis, traumatic ruptures, total joint replacements and revision cases were excluded. Only patients who underwent a complete physical examination after surgery were included in the study.

For each patient, all of the surgical notes and the first and most recent postoperative notes were reviewed. Patient demographics were captured in a spreadsheet which included age, gender, previous and additional surgery, revision surgery, medical issues, concomitant procedures, affected side and interference screw size. Information such as level of sports and worker compensation cases was also collated in the spreadsheet. Once a complication was found, it was noted in a separate spreadsheet to collate data and perform a final analysis.

\section{Surgical indications and technique}

The indications to surgically treat the biceps were based on clinical presentation of bicipital groove pain, partial or subtotal ruptures, degenerative superior labrum anterior and posterior lesions, long head of the biceps instability and positive provocative tests where pathology was confirmed by arthroscopic examination. The standardized technique consisted of an intra-articular release of the proximal portion of the remaining tendon either open or arthroscopically. With the arm internally rotated and abducted, the inferior border of the pectoralis major tendon was palpated and an incision made $1 \mathrm{~cm}$ superior to the inferior border and continued $1-2 \mathrm{~cm}$ below the inferior border as described by Millett et al. [1] and Mazzocca et al. [5]. The proximal portion of the tendon was resected and the remaining portion was fixed with a tenodesis interference screw (Arthrex, Naples, FL.) into a previously drilled bone tunnel of the same size. Soft tissues were closed in a standard fashion.

\section{Results}

Of the 636 patients who underwent biceps tenodesis, a total of 491 underwent subpectoral biceps tenodesis and met the study inclusion criteria. Of the patients, 31 were lost to follow-up, another 31 were revision cases from other centers that were excluded and the rest were patients who had either soft tissue tenodesis or partial or complete arthroplasty. The time for follow-up after the surgical procedure ranged from 1.1 to 6.7 years.

Of the 491 patients who had subpectoral biceps tenodesis, 344 were male patients $(70.1 \%)$ and 147 were female (29.9\%). A total of 39 patients $(7.4 \%)$ 
Obere Extremität 2014 · 9:276-279 DOI 10.1007/s11678-014-0276-y

(c) Springer-Verlag Berlin Heidelberg 2014

P.J. Millett · D. Rios · F. Martetschläger · M.P. Horan

\section{Complications following subpectoral biceps tenodesis with interference screw fixation}

Abstract

Background. Subpectoral biceps tenodesis is considered an effective and increasingly popular method to manage long head of the biceps tendon pathology and combined lesions of the biceps labral complex. The purpose of this study was to report the complications following this procedure in a large prospective group of patients using a consistent technique.

Hypothesis. Subpectoral biceps tenodesis is a safe and effective method for treating long head of the biceps pathology with a low complication rate.

Study design. Case series. Level of evidence IV.

Methods. This study had prior Institutional Review Board approval. Over a period of 5 years, 636 patients underwent subpectoral biceps tenodesis by the same surgeon. Patients who underwent subpectoral tenodesis with interference screws using a standardized technique were included in the analysis.
Those who underwent biceps tenodesis for a chronic long head biceps rupture, those who underwent concomitant shoulder arthroplasty and those who underwent revision biceps tenodesis were excluded. All patients included in the study also underwent a postoperative physical examination.

Results. From November of 2005 to June of 2011, 491 patients met the inclusion criteria, 344 patients were male, 147 female and 39 were worker compensation cases. Out of the 491 patients with subpectoral biceps tenodesis, complications occurred in $12 \mathrm{pa}$ tients of which 11 were considered minor and 1 was considered a major complication. The major complication was a proximal humerus fracture that occurred through the drill hole 2 weeks postoperatively. This was clearly due to a technical error where the drill hole was placed eccentrically in the humeral shaft. There were 11 minor complications; 5 cases had a rupture at the fixation site, 2 other cas- es had ruptures at the muscle-tendon junction site (distal to the tenodesis) and $1 \mathrm{pa}-$ tient had a rupture in continuity. Two cases had minor sprains that presented only with mild pain and resolved completely and one other case needed to be revised due to a prominent screw. All of the complications occurred within the first 2 months after surgery and 2 were in worker compensation cases. Conclusion. An overall complication rate of $2.4 \%$ validates the hypothesis of a low complication rate after subpectoral biceps tenodesis. These results support the conclusions from previous biomechanical studies that have shown good bone-tendon-screw interface fixation strength.

\section{Keywords}

Biceps subpectoral tenodesis .

Complications · Prospective study · Surgical procedures, operative · Follow up study

\section{Komplikationen nach subpektoraler Bizepstenodese und Fixierung mit Interferenzschrauben}

\section{Zusammenfassung}

Hintergrund. Die subpektorale Bizepstenodese wird als effektive, zunehmend eingesetzte Methode zum Management von Pathologien am langen Bizepskopf und von kombinierten Läsionen am Labrum-BizepsKomplex angesehen. Ziel der Studie ist es, Komplikationen nach dieser Intervention in einer konsistenten Operationstechnik an einem großen, prospektiven Patientenkollektiv zu dokumentieren.

Hypothese. Zur Behandlung von Pathologien am langen Bizepskopf ist die subpektorale Bizepstenodese eine sichere und effektive Methode, Komplikationen sind selten. Studiendesign. Fallserie, Evidenzlevel IV. Methoden. Für die Studie lag ein positives Votum der lokalen Ethikkommission vor. Über 5 Jahre hinweg unterzogen sich $636 \mathrm{~Pa}$ tienten einer subpektoralen Bizepstenodese, operiert wurden alle von demselben Chirurgen. In die Studie aufgenommen wurden Patienten, die mit einer subpektoralen Bizepstenodese unter Verwendung von Interferenzschrauben mit einer standardisierten Tech- nik versorgt worden waren. Ausgeschlossen dagegen wurden Patienten, die wegen einer chronischen Ruptur des langen Kopfes behandelt worden waren, die sich gleichzeitig einer Schulterarthroplastie unterzogen hatten, und Patienten, bei denen eine Bizepstenodese revidiert worden war. Alle in die Studie eingeschlossenen Patienten wurden auch postoperativ körperlich untersucht.

Ergebnisse. Zwischen November 2005 und Juni 2011 erfüllten 491 Patienten die Einschlusskriterien (344 Männer, 147 Frauen), bei 39 handelte es sich um BG(Berufsgenossenschaft)-Fälle. Bei 12 der 491 Patienten traten Komplikationen auf. Von diesen wurde eine Komplikation als schwerwiegend klassifiziert: eine proximale Humerusfraktur durch das Bohrloch 2 Wochen postoperativ. Sie war offensichtlich bedingt durch einen technischen Fehler, das Bohrloch war exzentrisch im Humerusschaft platziert. Als leichte Komplikationen wurden 11 eingestuft: 5 Rupturen an der Fixierungsstelle, 2 Rupturen am Muskel-Sehnen-Komplex (distal der Tenode- se) und eine komplette Ruptur. Bei 2 Patienten gab es kleinere Zerrungen, die nur wenig schmerzten und vollständig heilten, bei einem weiteren musste wegen einer hervorstehenden Schraube revidiert werden. Sämtliche Komplikationen traten innerhalb von 2 Monaten postoperativ auf, 2 von innen bei den BG-Fällen.

Fazit. Die Gesamtkomplikationsrate von $2,4 \%$ validiert unsere Hypothese einer geringen Komplikationsrate nach subpektoraler Bizepstenodese. Ferner bestätigt sie die Ergebnisse früherer biomechanischer Forschung, in der die gute Fixierung am Knochen-Sehnen-Schrauben-Interface nachgewiesen wurde.

\section{Schlüsselwörter}

Subpektorale Bizepstenodese · Komplikationen · Prospektive Studie . Operative chirurgische Interventionen . Follow-up-Studie were worker compensation cases and 457 patients $(93.1 \%)$ had concomitant procedures which included rotator cuff repair, subacromial decompression, labral repair, capsular release, nerve decompression, ac- romioclavicular reconstruction and debridement. A total of 34 patients (6.9\%) had an isolated subpectoral biceps tenodesis.
Out of the 491 patients, complications occurred in 12 (2.4\%), 9 in men and 3 in women. There was one major complication of a proximal humerus fracture that occurred through the tenodesis site 
2 weeks postoperatively which was clearly due to a technical error in the drill hole placement. Ruptures occurred at the fixation site in 5 cases, two other cases had ruptures at the muscle-tendon junction site (distal to the tenodesis) and one case had a rupture in continuity. Another two cases had minor sprains that resolved completely and one other case needed to be revised for a prominent screw and a new interference screw was placed. All of the complications occurred within the first 2 months after surgery and 2 of them were in worker compensation cases. Of the failures, 8 had fixation with a screw size $8 \times 12 \mathrm{~mm}, 3$ with a screw size $7 \times 12 \mathrm{~mm}$ and 1 had a $6.25 \times 12 \mathrm{~mm}$ screw for fixation. The mean age of patients with complications was 49 years (range 27-66 years), 8 patients needed a second surgery and 4 were treated conservatively.

\section{Discussion}

Previous studies have demonstrated that there is variability in the outcome and strength of fixation after subpectoral tenodesis [6-8]. The present study demonstrated a low complication rate of $2.4 \%$ following subpectoral biceps tenodesis with interference screw fixation. Nho et al. [4] described a series of 353 patients with a complication rate of $2.0 \%$.

This is one of the largest case studies examining the complications of subpectoral biceps tenodesis. A recent study has examined clinical outcomes for revision biceps tenodesis after subpectoral biceps tenodesis, finding improvements in clinical outcomes and patient satisfaction after the revision surgery [9].

In the present study, the analysis also showed that complications appeared early after surgery within the first year (usually in the first 2 months) which is consistent with other studies $[4,9]$ and indicates that complications most commonly arise from technical problems or issues with healing in the early postoperative period. While some of the patients in this study had a follow-up of less than 2 years, this time is considered acceptable because failures were typically seen in the early postoperative period and clinically no late failures have been reported [9].
Although the biomechanical role of the long head of the biceps tendon has yet to be defined [10], it can be a pain generator in the anterior shoulder and can be treated either by arthroscopic proximal or miniopen, distal subpectoral tenodesis [11-13] when the previously mentioned indications are encountered. Isolated tenotomy is another option for treating pathology of the long head of the biceps. Tenotomy may allow faster return to normal activities and decreased rehabilitation after surgery but it has resulted in unacceptable Popeye deformities and muscle cramp in some individuals [11].

While long head biceps pathology can be treated either by tenodesis, tenotomy or conservative treatment options, it has been shown that subpectoral biceps tenodesis provides a reliable means of treating pathologies of the biceps without cosmetic deformities and with alleviation of pain [1] with a low complication rate Limitations of the study include the retrospective nature and the lack of a control group to compare with the other available treatment options.

\section{Conclusion}

An overall complication rate of $2.4 \%$ validates the hypothesis of a low complication rate after subpectoral biceps tenodesis. These results support conclusions from previous biomechanical studies that have shown good bone-tendonscrew interface fixation strength. Further research is needed to compare results with isolated tenotomy and arthroscopic tenodesis and to define which of these options may have the best long-term outcome and the lowest rate of complications combined with the highest rate of patient satisfaction.

\section{Corresponding address}

\section{P.J. Millett MD, MSc}

The Steadman Clinic

181 West Meadow Drive, Suite 400, Vail, CO

drmillett@thesteadmanclinic.com

\section{Compliance with ethical guidelines}

Ethical standards statement. All procedures followed were in accordance with the ethical standards of the responsible committee on human experimentation (institutional and national) and with the Helsinki Declaration of 1975, as revised in 2008 (5).

Informed consent. Informed consent was obtained from all patients before being included in the study.

Conflicts of interest. Peter J. Millett has received from Arthrex something of value (exceeding the equivalent of US\$500) not related to this manuscript or research. He is a consultant and receives royalties from Arthrex and has stock options in Game Ready and VuMedi. Marilee P. Horan, her immediate family, and any research foundations with which she is affiliated have not received any financial payments or other benefits from any commercial entity related to the subject of this research. Daniel Rios, his immediate family, and any research foundations with which he is affiliated have not received any financial payments or other benefits from any commercial entity related to the subject of this research. Frank Martetschläger has received from Arthrex something of value (exceeding the equivalent of US\$500) not related to this manuscript or research. His position was sponsored by Arthrex. This research was supported by the Steadman Philippon Research Institute which is a 501 (c)(3) non-profit institution supported financially by private donations and corporate support from the following entities: Smith \& Nephew Endoscopy, Arthrex, Siemens Medical Solutions, Conmed Linvatec, Össur Americas, Synthes, and Ceterix Orthopaedics.

\section{References}

1. Millett PJ, Sanders B, Gobezie R, Braun S, Warner JJP (2008) Interference screw vs. suture anchor fixation for open subpectoral biceps tenodesis: does it matter? BMC Musculoskelet Disord 9(1):121

2. Lo IK, Burkhart SS (2004) Arthroscopic biceps tenodesis using a bioabsorbable interference screw. Arthroscopy 20(1):85-95

3. Mazzocca AD, Cote MP, Arciero CL, Romeo AA, Arciero RA (2008) Clinical outcomes after subpectoral biceps tenodesis with an interference screw. Am J Sports Med 36(10):1922-1929

4. Nho SJ, Cole BJ, Mazzocca AD, Williams JM et al (2006) Comparison of ultrasonic suture welding and traditional knot tying in a rabbit rotator cuff repair model. J Shoulder Elbow Surg 15(5):630-638

5. Mazzocca AD, Rios CG, Romeo AA, Arciero RA (2005) Subpectoral biceps tenodesis with interference screw fixation. Arthroscopy 21(7):896

6. Richards DP, Burkhart SS (2005) A biomechanical analysis of two biceps tenodesis fixation techniques. Arthroscopy 21(7):861-866

7. Ozalay M, Akpinar S, Karaeminogullari $O$ et al (2005) Mechanical strength of four different biceps tenodesis techniques. Arthroscopy 21(8):992-998

8. Mazzocca AD, Bicos J, Santangelo S, Romeo AA, Arciero RA (2005) The biomechanical evaluation of four fixation techniques for proximal biceps tenodesis. Arthroscopy 21(11):1296-1306

9. Gregory JM, Harwood DP, Gochanour E, Sherman SL, Romeo AA (2012) Clinical outcomes of revision biceps tenodesis. Int J Shoulder Surg 6(2):45-50 
10. Giphart EJ, Elser F, Dewing CB, Torry MR, Millett PJ (2012) The long head biceps tendon has minimal effect on in vivo glenohumeral kinematics. A biplane fluoroscopy study. Am J Sports Med 40(1):202-212

11. Szabó I, Boileau P, Walch G (2008) The proximal biceps as a pain generator and results of tenotomy. Sports Med Arthrosc 16(3):180-186

12. Kelly AM, Drakos MC, Fealy S et al (2005) Arthroscopic release of the long head of the biceps tendon: functional outcome and clinical results. Am J Sports Med 33(2):208-213

13. Elser F, Braun S, Dewing CB, Giphart JE, Millett PJ (2011) Anatomy, function, injuries, and treatment of the long head of the biceps brachii tendon. $\mathrm{Ar}$ throscopy 27(4):581-592 